\title{
ANALISIS PENGARUH WAKAF PRODUKTIF TERHADAP KESEJAHTERAAN MASYARAKAT DI MUKIM MATANG PANYANG
}

\author{
Munardi, Damanhur, \& Mulyana Fitri \\ Program Studi Ekonomi Syariah, Fakultas Ekonomi dan Bisnis, Universitas Malikussaleh \\ Email: mulyanafitri4@gmail.com
}

\begin{abstract}
This study aimed to determine the effect of productive endowment on community welfare in Matang Panyang. This study used primary data obtained by distributing questionnaires to 30 respondents who were selected using the Purposive sampling technique. The data analysis method used was a simple linear regression method with the help of EVIEWS. Based on the test of the correlation coefficient of 0.837835, it showed that productive endowment had a strong relationship to improve community welfare. Based on the coefficient determination test, it showed that productive endowment had an effect of $70.19 \%$ on community welfare. From the results of the study, it revealed that productive endowment $(X)$ significantly influenced the welfare community $(Y)$. Based on the t-value of 8.120918 and the t-table value of 2.04841 with a significant level of 0.0000 , it concluded that these tests accepted Ha and rejected Ho.
\end{abstract}

Keywords: welfare, productive endowment

\begin{abstract}
Abstrak: Penelitian ini bertujuan untuk mengetahui pengaruh wakaf produktif terhadap kesejahteraan masyarakat di mukim Matang Panyang. Penelitian ini menggunakan data primer yang diperoleh dengan cara membagikan kuisoner kepada 30 responden yang dipilih menggunakan teknik Purpossive sampling. Metode analisis data yang digunakan adalah metode regresi linear sederhana dengan bantuan EVIEWS. Berdasarkan pengujian koefisien korelasi sebesar 0,837835 menunjukkan bahwa wakaf produktif memiliki hubungan yang kuat terhadap meningkatnya kesejahteraan masyarakat. Berdasarkan pengujian dengan koefisien diterminasi diketahui bahwa wakaf produktif berpengaruh sebesar $70.19 \%$ terhadap kesejahteraan masyarakat. Dari hasil penelitian maka diperoleh bahwa wakaf produktif $(X)$ berpengaruh secara signifikan terhadap kesejahteraan masyarakat $(Y)$. Berdasarkan nilai t-hitung sebesar 8.120918 sedangkan nilai t-tabel sebesar 2.04841 dengan tingkat signifikan 0.0000 dengan kata lain pengujian ini menerima Ha dan menolak Ho.
\end{abstract}

Keywords: kesejahteraan, wakaf produktif 


\section{PENDAHULUAN}

Indonesia merupakan salah satu negara dengan luas dan kekayaan terbesar yang ada di dunia sehingga Indonesia memiliki potensi yang sangat besar. Salah satu potensi yang dapat dimanfaatkan adalah sumber daya alamnya, seperti tanah yang dapat diproduktifkan. Dalam Islam, adanya sistem wakaf yang merupakan instumen sosial yang dapat memanfaatkan tanah secara produktif. Di Indonesia pada tahun 1991 tercatat bahwa tanah wakaf mencapai 319.214 lokasi (Hafsah, 2009).

Pengelolaan wakaf dengan baik dapat menciptakan kesejahteraan masyarakat dan pengentasan kemiskinan. Namun sangat disayangkan, pengelolaan wakaf di Indonesia masih kurang mengarah kepada pemberdayaan ekonomi tetapi hanya sebatas keagamaan/ibadah saja (Nafik, Ryandono, \& Hazami, 2016).

Pengelolaan wakaf di Indonesia mengalami perubahan dan perkembangan yang signifikan, setelah tahun 2004 lahir undang-undang perwaqafan yaitu UU No 41 tahun 2004, bisa dikatakan bahwa ini merupakan suatu kemajuan yang sangat signifikan bagi umat islam di Indonesia. Setelah diresmikannya UU No 41 tahun 2004 lalu dibentuklah Badan Wakaf Indonesia (BWI) yang merupakan lembaga independen untuk mengelola dana wakaf secara khusus dan beroperasi dalam skala nasional. Tugas lembaga ini adalah mengembangkan dan memajukan perwaqafan yang ada di Indonesia (Nafik et al., 2016).

Wakaf produktif adalah pemanfaatan dan pengelolaan donasi wakaf dari umat yang di produktifkan donasi tersebut, sehingga dapat menghasilkan manfaat secara berkelanjutan. Donasi wakaf produktif tidak hanya berupa benda tidak bergerak, seperti tanah dan bangunan, namun juga dapat berupa benda yang bergerak, seperti uang, logam mulia, surat berharga dan lain sebagainya. Surplus wakaf produktif inilah yang akan menjadi sumber dana umat sehingga dapat dimanfaatkan untuk meningkatkan kesejahteraan masyarakat (Mubarok, 2008).

Dalam mengembangkan wakaf produktif, masalah yang timbul adalah mayoritas tanah wakaf di Indonesia dimanfaatkan hanya untuk kuburan dan mesjid sehingga tidak ada unsur ekonomi di dalamnya. Padahal tanah wakaf ini bisa dimanfaatkan dengan cara yang produktif, salah satunya adalah sawah yang bisa menghasilkan secara berkelanjutan. Inilah yang ada Mesjid Istiqamah Kemukiman Matang Panyang, yang mana terdapat 6 desa yang ada dalam kemukiman ini adalah desa Matang Sagoe, Matang Mesjid, Matang Cot Paseh, Cot Panjoe, Paya Meuneng dan Paya Leupah. Ke enam desa ini memanfaatkan tanah wakaf secara produktif yaitu sawah yang diberikan kepada masyarakat untuk dikelola dan akan dibagi keuntungan nantinya.

Tabel 1. Daftar Penerimaan Wakaf Sawah mesjid Istiqamah Matang Panyang

\begin{tabular}{clrrr} 
No. & \multicolumn{1}{c}{ Desa } & \multicolumn{1}{c}{$\begin{array}{c}\text { Jumlah wakaf } \\
\text { produktif }\end{array}$} & $\begin{array}{c}\text { Luas Lahan } \\
\text { Hasil Wakaf produktif yang } \\
\text { diterima oleh Masjid Istiqamah }\end{array}$ \\
\hline 1 & Matang Mesjid & 54 petak tanah sawah & $51,975 \mathrm{~m}^{2}$ & Rp. 44.327.000 \\
2 & Matang Sagoe & 14 petak tanah sawah & $12,548 \mathrm{~m}^{2}$ & Rp. 11.046 .000 \\
3 & Matang Cot Paseh & 11 petak tanah sawah & $16,175 \mathrm{~m}^{2}$ & Rp. 11.261 .250 \\
4 & Cot Panjoe & 11 petak tanah sawah & $12,809 \mathrm{~m}^{2}$ & Rp. 11.667 .000 \\
5 & Paya Meuneng & 5 petak tanah sawah & $8,730 \mathrm{~m}^{2}$ & Rp. 3.890.500 \\
6 & Paya Lipah & 4 petak tanah sawah & $3,641 \mathrm{~m}^{2}$ & Rp. 2.347.000 \\
\multicolumn{2}{l}{ Jumlah } & 99 petak tanah sawah & $105,878 \mathrm{~m}^{2}$ & Rp. 84.538 .750 \\
\hline
\end{tabular}

Sumber: Bendahara Mesjid Istiqamah (2018).

Dari tabel tersebut diketahui bahwa ada 6 desa yang menjadi bagian dari wakaf mesjid istiqamah, dan yang menjadi jumlah tanah wakaf terbanyak adalah desa Matang mesjid dan Matang Sagoe yang memiliki 68 petak tanah wakaf produktif. Sedangkan keempat desa yang lain hanya memili 31 petak tanah sawah yang merupakan harta wakaf. Saya mengambil sampel penelitian di kedua desa yaitu Matang Mesjid dan Matang Sagoe karena memiliki jumlah tanah wakaf terbanyak yang bisa saya teliti.

Kita tahu betapa besar potensi wakaf jika bisa dikembangkan dengan baik, apalagi jika memanfaatkan wakaf produktif. Inilah yang membuat saya tertarik untuk mengambil penelitian tentang wakaf ini, namun menurut saya wakaf 
produktif cenderung dapat meningatkan ekonomi umat yang mana harus berdasarkan kepada kesejahteraan umat. Maka yang menjadi pokok permasalahan dalam penelitian ini adalah seberapa besar pengaruh wakaf produktif terhadap kesejahteraan mayarakat di Mukim Matang Panyang.

\section{TINJAUAN PUSTAKA \\ Pengertian Wakaf}

Wakaf secara bahasa berasal dari bahasa arab "waqafa" yang berarti menahan, tetap dan mencegah. Kata "waqf" sama maknanya dengan kata "al-habs" yang berarti sama-sama mencegah atau sesuatu yang ditahan (Kamus Besar Bahasa Indonesia). Jadi bisa dikatakan bahwa wakaf adalah aset atau harta seseorang atau kaum muslimin yang diperuntukkan untuk kemashlahatan orang banyak, namun benda wakafnya yang asli harus tetap atau ditahan, tidak boleh diperjual-belikan (Anas \& Ryandono, 2016).

Dalam hukum islam, wakaf didefinisikan sebagai menahan suatu benda agar tidak berpindah kepemilikan untuk selama-lamanya dan mendonasikan hasil/manfaatnya untuk kepentingan orang-orang miskin atau untuk tujuan kebaikan (Munir, 2015).

Rukun wakaf ada 4 (empat):

1. Orang yang mewakafkan hartanya (waqif)

2. Barang/benda yang diwakafkan (mawquf bih)

3. Orang yang diserahi harta wakaf (mawquf 'alaih)

4. Ungkapan orang yang mewakafkan harta bendanya (sighat)

5. Orang yang mengelola (nazir) (AlHadi, 2009).

Sedangkan syarat-syarat wakif adalah

1. Orang yang merdeka (bukan budak/hamba sahaya)

2. Harta yang diwakafkan haruslah miliknya sendiri

3. Baliqh dan berakal sehat (Munir, 2015).

\section{Pengertian Wakaf Produktif}

Wakaf produktif adalah pemanfaatan dan pengelolaan donasi wakaf dari umat yang di produktifkan donasi tersebu, sehingga dapat menghasilkan manfaat secara berkelanjutan. Donasi wakaf produktif tidak hanya berupa benda tidak bergerak, seperti tanah dan bangunan, namun juga dapat berupa benda yang bergerak, seperti uang, logam mulia, surat berharga dan lain sebagainya. Surplus wakaf produktif inilah yang akan menjadi sumber dana umat sehingga dapat dimanfaatkan untuk meningkatkan kesejahteraan masyarakat (Mubarok, 2008).

Wakaf produktif berlaku untuk memperoleh manfaat yang lebih besar dan berlaku jangka panjang pada harta wakaf guna untuk menopang berbagai aktivitas ekonomi, sosial dan keagamaan. Wakaf produktif pada umunya berupa tanah pertanian dan tanah perkebunan, gedunggedung komersial yang dikelola untuk mendatangkan hasi dan keuntungan yang dapat dimanfaatkan untuk kepentingan dan kemashlahatan umat (Medias, 2010).

Di Indonesia sangat disayangkan bahwa pemahaman tentang wakaf hanya sebatas benda yang tidak bergerak saja seperti kuburan, mesjid dan lainnya. Namun setelah adanya UU No 41 tahun 2004 ini menjadi titik terang untuk sistem perwakafan di Indonesia. Karena menurut undangundang ini, harta wakaf tidak hanya benda yang tidak bergerak namun juga termasuk kedalamnya benda yang bergerak, seperti uang, logam mulia, surat berharga dan lain sebagainya. Jadi walaupun dalam bentuk yang produktif, pengelolaan wakaf haruslah sesuai dengan tujuan wakaf yaitu untuk mencapai kemashlahatan dan kesejahteraan masyarakat secara umum (Mubarok, 2008).

\section{Pengertian Kesejahteraan}

Dalam Islam masyarakat kesejahteraan itu tidak hanya dilihat dari materi saja, namun juga ada nilai non materinya, seperti spritual dan moral. Masyarakat bisa dikatakan sejahtera jika terpenuhinya 2 kriteria, yaitu: terpenuhinya kebutuhan pokok manusia seperti: makanan, minuman, pakian, tempat tinggal, pendidikan, kesehatan dan lainnya. Yang kedua adalah terjaga dan terlidunginya agama, harta, jiwa, akal, dan kehormatan manusia (Damanhur, 2016).

Upaya untuk meningkatkan kesejahteraan bisa dilakukan dengan meningkatkan pendapatan dan mengurangi kemiskinan (Sodiq, 2016). Ini tidak bisa dipungkiri bahwa ketika pendapatan suatu negara mulai bagus maka akan dilakukan distribusi pendapatan yang mana dapat meningkatkan kesejahteraan masyarakat. Begitu pun dengan kemiskinan, ketika tingkat kemiskinan menurun maka bisa dikatakan masyarakat menjadi lehih sejahtera. 
Pendapatan adalah seluruh penerimaan baik berupa uang ataupun barang yang diberikan oleh pihak lain maupun dari hasil kerja sendiri, dengan adanya nilai harga yang berlaku saat ini yang diperolehnya untuk suatu jangka waktu tertentu (Eryanto \& Rika, 2013).

Pendapatan adalah jumlah penghasilan yang disumbangkan atau diberikan oleh seluruh anggota keluarga yang digunakan untuk memenuhi kebutuhan bersama maupun individu dalam rumah tangga. Jumlah anggota keluarga dapat menentukan jumlah kebutuhan yang harus ditanggung dan dipenuhi, semakin banyak anggota keluarga maka semakin banyak pula kebutuhan yang harus dipenuhi oleh rumah tangga (Wiratmadja, 2005).

Jadi dapat dikatakan, bahwa pendapatan adalah hasil yang didapat sesorang dari kerja kerasnya, berupa uang atau materi yang dapat digunakan untuk memenuhi kebutuhan hidupnya.

Hal ini berarti menjadikan wakaf produktif sebagai media untuk menciptakan keadilan ekonomi, mengurangi kefakiran dan kemiskinan, mengembangkan sistem jaminan sosial, dan menyediakan fasilitas pelayanan kesehatan serta fasilitas pelayanan umum yang baik. Wakaf produktif ini menjadi alternative yang baik untuk perbaikan konomi dan peningkatan kesejahteraan masyarakat banyak (Abdurrohman Kasdi, 2017).

\section{Penelitian Terdahulu}

Berkaitan dengan penelitian ini ada beberapa penelitian yang telah dilakukan oleh peneliti lain sebelumnya yang permasalahannya hampir sama dengan penelitian yang sedang penulis lakukan.

Tabel 2. Penelitian Terdahulu

\begin{tabular}{|c|c|c|}
\hline Penulis/Judul Jurnal & Yang di teliti penulis & Yang kita teliti \\
\hline $\begin{array}{l}\text { Fahruddin Ali Sabri "Wakaf } \\
\text { Uang (Sebuah Alternatif dalam } \\
\text { Upaya Menyejahterakan } \\
\text { Masyarakat)" }\end{array}$ & $\begin{array}{l}\text { Penulis meneliti tentang wakaf uang } \\
\text { yang dapat menjadi istrumen } \\
\text { ekonomi untuk menyelesaikan } \\
\text { persoalan kemiskinan dan } \\
\text { kesenjangan, sehingga dapat } \\
\text { membuat masyarakat menjasi } \\
\text { sejahtera. }\end{array}$ & $\begin{array}{l}\text { Saya meneliti tentang wakaf } \\
\text { produktif dan } \\
\text { terhadap } \\
\text { masyrakat. }\end{array}$ \\
\hline $\begin{array}{l}\text { Abdurrahman Kasdi "Model } \\
\text { Pemberdayaan Wakaf } \\
\text { Produktif Di Indonesia", }\end{array}$ & $\begin{array}{l}\text { Penulis meneliti bagaimana bentuk } \\
\text { atau model pemberdayaan wakaf } \\
\text { produktif si Indonesia, seperti } \\
\text { pemberdayaan wakaf rumah sakit, } \\
\text { pemberdayaan wakaf bisbis center, } \\
\text { menginvestasikan asset wakaf dan } \\
\text { wakaf untuk pendidikan. }\end{array}$ & $\begin{array}{l}\text { Yang saya teliti hanya satu model } \\
\text { wakaf produktif saja yaitu } \\
\text { pemanfaatan tanah wakaf untuk } \\
\text { membantu mensejahterakan } \\
\text { masyarakat. }\end{array}$ \\
\hline $\begin{array}{l}\text { M. Nur Rianto Al Arif "Wakaf } \\
\text { Uang Dan Pengaruhnya } \\
\text { Terhadap Program } \\
\text { Pengentasan Kemiskinan Di } \\
\text { Indonesia" }\end{array}$ & $\begin{array}{l}\text { Penulis meneliti tentang wakaf } \\
\text { tunai, program pengentasan } \\
\text { kemiskinan dan sistem jaminan } \\
\text { sosial. Metode penelitian yang } \\
\text { dipakai adalah kepustakaan dan } \\
\text { observasi. }\end{array}$ & $\begin{array}{l}\text { Penelitian saya membahas zakat } \\
\text { produktif secara umum dan } \\
\text { sedikit menerangkan tentang } \\
\text { wakaf uang. Metode penelitian } \\
\text { yang dipakai adalah survey, } \\
\text { wawancara dan kuisoner. }\end{array}$ \\
\hline
\end{tabular}

\section{Kerangka Konseptual}

Penelitian ini akan menganalisis kesejahteraan masyarakat di mukim Matang Panyang di kabupaten Bireuen. Dan kerangka konseptualnya dapat digambarkan sebagai berikut :

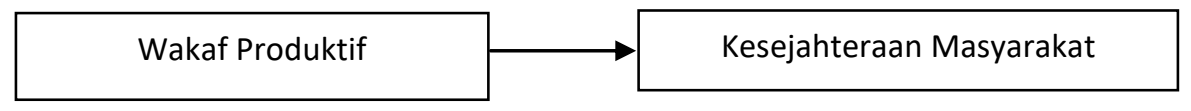

Uji t

Gambar 1. Kerangka Konseptual

\section{Hipotesis}

Dalam penelitian ini dirumuskan hipotesis guna memberikan arah dan pedoman dalam melakukan penelitian. Hipotesis yang digunakan dalam penelitian ini adalah:
$\mathrm{H}_{0}$ : Diduga wakaf produktif tidak berpengaruh terhadap meningkatnya kesejahteraan masyarakat di mukim Matang Panyang 
Ha: Diduga wakaf produktif berpengaruh terhadap meningkatnya kesejahteraan masyarakat di mukim Matang Panyang.

\section{METODE PENELITIAN}

\section{Lokasi dan Objek Penelitian}

Dalam melakukan penelitian ini, penulis memilih Lokasi di Mukim Matang Panyang, Kecamatan Peusangan Kabupaten Bireuen, sedangkan yang menjadi objek penelitian warga yang membajak tanah wakaf milik Mesjid Istiqamah.

\section{Populasi dan Sampel}

Supranto (2001) mengatakan bahwa populasi adalah totalitas dari semua objek atau individu yang menjadi karakteristik tertentu dan lengkap yang akan diteliti. Sedangkan sampel adalah kumpulan elemen yang merupakan bagian kecil dari populasi.

Populasi dalam penelitian ini adalah seluruh masyarakat yang menggarap tanah sawah yang merupakan aset wakaf yang dikelola oleh Mesjid Istiqamah di mukim Matang Panyang yang mana yang menjadi tempat penelitian yaitu 2 desa yang memiliki populasi sebanyak 68 petani yang menjadi penggarap tanah wakaf tersebut. Pengambilan sampel pada penelitian ini menggunakan purposive sampling dimana peneliti menetukan pengambilan sampel dengan cara menetapkan ciri yang khusus sesuai dengan tujuan penelitian. Jadi sampel yang di ambil pada penelitian ini sebanyak 30 orang responden.

\section{Teknik Pengumpulan Data}

Dalam rangka mengumpulkan data-data untuk tujuan penelitian berupa data primer maka penulis melakukan dengan cara :

1. Field Research (Penelitian Lapangan) Penelitian ini dilakukan untuk mendapatkan data primer dengan cara mendatangi objek yang akan diteliti. Tujuan yang diharapkan adalah untuk memperoleh data secara langsung di lapangan. Teknik yang dipergunakan adalah:

a. Kuesioner (Questioner) Teknik pengumpulan data dengan memberikan pertanyaan langsung kepada responden.

b. Dokumentasi Menganalisis data-data yang berupa dokumen-dokumen yang berasal dari pihak bendahara Masjid Istiqamah kemukiman Matang Panyang yang berkaitan langsung dengan objek penelitian penulis.
2. Data Kepustakaan (Library Research) Pada penelitian ini diperoleh data sumber-sumber seperti buku, jurnal yang diakses oleh penulis untuk membantu dalam penulisan. Penulis banyak mendapatkan bantuan dari jurnaljurnal penelitian sebelumnya untuk menyelesaikan penulisannya.

\section{Metode Analisis}

Metode analisis data yang digunakan pada penelitian ini adalah Metode kuantitatif yaitu dalam mpengambilan data secara statistik untuk mempermudah perhitungannya dengan menggunakan angka-angka statistik. Untuk menguji kebenaran hipotesis yang diajukan, maka model yang digunakan adalah model regresi linier sederhana dengan menggunakan bantuan software eviews. Rumus secara matematis: 
Keterangan:

$$
\begin{aligned}
& \text { Y : Kesejahteraan Masyarakat } \\
& \text { a : Konstanta } \\
& \text { b : Koefisien Regresi } \\
& \text { X : Wakaf Produktif } \\
& \text { e : Error Team }
\end{aligned}
$$

\section{Definisi Operasional Variabel}

Definisi operasional variabel dalam penelitian ini adalah sebagai berikut :

1. Kesejahteraan Mayarakat (Y) sebagai variable terikat (dependent): jumlah pendapatan yang diterima masyarakat setelah memanfaatkan tanah wakaf tersebut atau masyarakat yang mengelola tanah wakaf milik mesjid Istiqamah Mukim Matang Panyang (diukur dalam bentuk rupiah).

2. Wakaf Produktif (X) sebagai variabel bebas (independent): jumlah biaya (modal produksi) yang dikeluarkan selama proses produksi tanah wakaf yang di lakukan oleh masyarakat di mukim Matang Panyang (diukur dalam bentuk rupiah).

\section{Uji Asumsi Klasik}

\section{a. Uji Normalitas}

Menurut Gujarati (2009) uji normalitas data bertujuan untuk menguji apakah dalam model regresi, baik variabel dependen maupun variabel independen keduanya memiliki distribusi normal atau tidak. Model regresi yang baik adalah model regresi yang mempunyai distribusi normal atau mendekati normal, yaitu distribusi data tersebut tidak menceng ke kanan dan ke kiri.

Untuk uji normalitas data, untuk melihat normalitas residual penulis melihat dengan JarqueBera. Untuk mendeteksi residualnya terdistribusi normal atau tidak dengan membandingkan statistic Jarque-Bera

a. Jarque-Bera $(\mathrm{JB})<$ Chi-Square dari alpha 5\% maka uji normalitas diterima, berarti bahwa data residual terdistribusi secara normal

b. Jarque-Bera $(\mathrm{JB})>$ Chi-Square dari alpha 5\%, berarti residual tidak terdistribusi normal.

\section{b. Uji Heteroskedastisitas}

Menurut Gujarati (2009) uji

heteroskedastisitas bertujuan untuk menguji apakah dalam model regresi linier terjadi kesamaan variance dari residual satu pengamatan ke pengamatan lain. Model regresi yang baik adalah yang homoskedastisitas atau tidak terjadi heteroskedastisitas. Pengujian pada penelitian ini menggunakan grafik Plot dari variabel yang digunakan dalam penelitian. Jika diagram plot yang dibentuk menunjukkan pola tertentu maka dapat dikatakan model tersebut mengandung gejala heterokedastisitas.

\section{Pengujian Hipotesis (Uji-T)}

Meurut Ghozali (2012) untuk mengetahui pengaruh variabel bebas secara parsial atau individu terhadap variable tidak bebas dengan asumsi variabel yang lain konstan. Pengujian ini dilakukan dengan melihat derajat signifikansi masing-masing variabel bebas. Pengujian hipotesis menggunakan uji $\mathrm{t}$, menggunakan tingkat keyakinan (level of signifikan) atau $\alpha=0,05$ dengan ketentuan :

1. Jika probabilitas (signifikansi) $>0,05(\alpha)$ maka Ho diterima dan Ha ditolak

2. Jika probabilitas (signifikansi) $<0,05(\alpha)$ maka Ho ditolak dan Ha diterima.

Uji t digunakan untuk mengetahui apakah wakaf produktif $(\mathrm{X})$ berpengaruh terhadap variabel terikat kesejahteraan masyarakat $(\mathrm{Y})$ dengan asumsi variabel bebas lain konstan.

\section{Koefisien Korelasi (R) dan Koefisien Diterminasi $\left(\mathbf{R}^{2}\right)$}

\section{a. Uji Koefisien Korelasi (R)}

Menurut Gujarati (2009), koefisien korelasi merupakan ukuran kedua yang dapat digunakan untuk mengetahui bagaimana keeratan hubungan antara suatu variabel dengan variabel lain - Jika koefisien korelasi berhubungan dengan sampel yang digunakan, maka koefisien korelasi (diberi simbol r) besarnya adalah akar dari koefisien diterminasi.

\section{b. Koefisien Diterminasi $\left(\mathbf{R}^{2}\right)$}

Menurut Gujarati (2009), koefisien determinasi adalah untuk mengetahui seberapa besar persentase sumbangan variabel bebas terhadap variabel terikat yang dapat dinyatakan dalam persentase. Namun tidak dapat dipungkiri ada kalanya dalam penggunaan koefisien determinasi $\left(\mathrm{R}^{2}\right)$ terjadi bias terhadap satu variabel bebas yang dimasukkan dalam model. Sebagai ukuran kesesuaian garis regresi dengan sebaran data, $\mathrm{R}^{2}$ menghadapi masalah karena tidak memperhitungkan derajat bebas.

Kelemahan mendasar penggunaan determinasi adalah bias terhadap jumlah variabel 
independen yang dimasukkan ke dalam model. Setiap tambahan satu variabel pasti meningkat tidak peduli apakah variabel tersebut berpengaruh secara signifikan terhadap variabel dependen. Oleh karena itu, banyak peneliti menganjurkan untuk menggunakan nilai $R$ - Squared $\left(\mathrm{R}^{2}\right)$ pada saat mengevaluasi model regresi yang terbaik.

\section{HASIL PENELITIAN DAN PEMBAHASAN Hasil Penelitian}

\section{a. Gambaran Umum Objek Penelitian}

Objek penelitiannya adalah masyarakat yang membajak tanak wakaf milik mesjid istiqamah yang terletak di desa Matang Mesjid, kemukiman Matang Panyang. Kemukiman Matang Panyang merupakan salah satu kemukiman di kecamatan Peusangan kabupaten Bireuen Provinsi Aceh. Secara geografis, kemukiman Matang Panyang berada di sebelah timur kabupaten Bireuen dengan jarak sekitar 25 kilometer. Adapun secara administratif, kemukiman Matang Panyang berbatas dengan kemukiman Matang Glumpang Baro, Glumpang Tujoh dan Teungku di Krueng.

\section{b. Karakteristik Responden}

Karakteristik individu responden yang dipaparkan berdasarkan jenis kelamin, status pernikahan, umur, tingkat pendidikan dan pekerjaan.

Berdasarkan penelitian, dapat diketahui bahwa 27 orang atau $90 \%$ adalah responden perempuan dan 3 orang atau $10 \%$ respondennya adalah laki-laki. Dari data ini juga terlihat bahwa jumlah responden perempuan lebih besar daripada jumlah responden laki-laki. Ini dikarenakan banyaknya jumlah perempuan dan laki-laki dan bahkan banyak dari penerima tanah wakaf ini merupakan janda.

Dan status pernikahan responden paling banyak adalah menikah, dan selanjutnya janda/duda dan terakhir baru belum menikah. Responden yang belum menikah hanya 2 orang saja, yaitu berjenis kelamin perempuan. Untuk reponden pada no 3 (janda/duda) hanya berjenis kelamin perempuan saja atau janda. Para ibu-ibu yang sudah tidak memiliki suami diberikan bantuan berupa tanah wakaf yang dapat dimanfaatkannya untuk memenuhi kebutuhan hidupnya, rata-rata janda yang mendapat tanah wakaf ini berumur 50 tahun sampai 51 tahun ke atas. Dikarenakan para janda ini tidak memiliki pendapatan lain dan rata-rata berprofesi sebagai ibu rumah tangga dan petani.

Responden paling muda berumur 26 tahun dan yang paling tua berumur 65 tahun. Dari data menunjukkan bahwa ada 9 orang responden atau $30 \%$ telah menempuh pendidikan Sekolah Dasar atau Madrasah Ibtidayah, 6 orang responden atau $20 \%$ telah menempuh pendidikan Sekolah Menengah Pertama atau Madrasah Tsanawiyah, 13 orang responden atau $43 \%$ telah menempuh pendidikan Sekolah Menengah Atas atau Madrasah Aliyah, dan 2 orang responden atau 7\% telah menempuh pendidikan Sarjana (S1). Masyarakat yang menjadi responden paling banyak menempuh pendidikan terakhir SMA/MA, jadi bisa dikatakan bahwa pendidikan responden cukup tinggi dan ini dapat mempengaruhi produktifitas masyarkat dalam mengelola tanah wakaf. Jadi dari penelitian ini, dapat diketahui bahwa tidak ada satu responden pun yang tidak bersekolah. Jadi bisa dikatakan bahwa tingkat pendidikan di daerah mukim matang panyang ini tergolong baik.

Dan pekerjaan responden dapat diketahui bahwa 12 orang atau $40 \%$ reponden berprofesi sebagai petani dan 18 orang responden atau $60 \%$ berprofesi sebagai IRT (Ibu Rumah Tangga).

\section{Hasil Pengujian Asumsi Klasik}

\section{a. Uji Normalitas}

Uji normalitas dilakukan dengan tujuan untuk melihat apakah variabel dependen dan variabel independen dalam model regresi berdistribusi normal. Uji normalitas yang dilakukan dalam pengujian ini menggunakan aplikasi Eviews, dan melihat nilai residual dari Jarque-Bera. Residual dikatakan memiliki distribusi normal apabila nilai signifikan dari Jarque-Bera di atas 5\% dan residual tidak terdistribusi secara normal jika signifikan nilai dari Jarque-Bera di bawah $5 \%$. Adapun hasil pengujian data ditunjukkan sebagai berikut: 


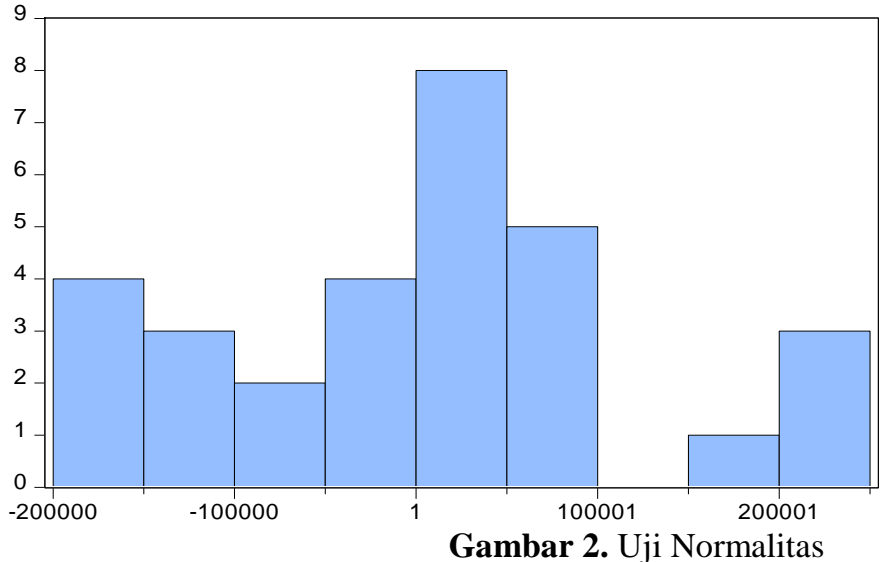

\begin{tabular}{|lr|}
\hline \multicolumn{2}{|l|}{ Series: Residuals } \\
Sample 130 \\
Observations 30 \\
Mean & $-1.84 \mathrm{e}-11$ \\
Median & 588.9282 \\
Maximum & 220200.2 \\
Minimum & -199411.1 \\
Std. Dev. & 120319.9 \\
Skewness & 0.096298 \\
Kurtosis & 2.403317 \\
& \\
Jarque-Bera & 0.491405 \\
Probability & 0.782155 \\
\hline
\end{tabular}

Maka dari hasil pengujian pada gambar 4.1 dapat disimpulkan bahwa nilai residual dari persamaan regresi di atas terdistribusi normal karena nilai Jarque-Bera $=0,49$ lebih kecil dari 5,99 atau probabiltas Jarque-Bera $=0,782$ lebih besar dari 0,05 .

\section{b. Uji Heterokedastisitas}

Pengujian heterokedastisitas bertujuan untuk melihat apakah setiap variabel pengganggu mempunyai variabel yang sama atau tidak. Ada berbagai cara untuk dapat mendeteksi adanya heterokedastisitas, yaitu menggunakan uji White test, Harvey test, Glejsier test, ARCH test, Breusch Pagan Godfrey test dan peneliti untuk mendeteksi heterokedastisitas menggunakan uji harvey heterokedasticity dengan menggunakan software Eviews.

Tabel 3. Uji Heterokedastisitas

Heteroskedasticity Test: Harvey

\begin{tabular}{lllr}
\hline F-statistic & 0.099318 & Prob. F(1,28) & 0.7550 \\
\hline Obs*R-squared & 0.106037 & Prob. Chi-Square(1) & 0.7447 \\
\hline Scaled explained SS & 0.351115 & Prob. Chi-Square(1) & 0.5535 \\
\hline
\end{tabular}

Dari hasil output di atas tampak bahwa nilai $o b s * R$ Square pada uji Harvey adalah sebesar 0,106 lebih kecil dari 5,99 dan probabilitas chi-Square 0,745 lebih besar dari 0,05 yang berarti bahwa tidak terdeteksi heterokedastisitas.

\section{Pembahasan Hasil Penelitian Regresi Linier Sederhana}

Dari penelitian penulis yang telah penulis dapatkan dari hasil olah data, maka berikut ini adalah hasilnya dalam bentuk statistik.

Tabel 4. Regresi Linier Sederhana

Dependent Variable: PENDAPATAN_SETELAH_WAKAF__Y

Method: Least Squares

Date: 05/08/19 Time: 14:40

\begin{tabular}{cccrr}
\hline \multicolumn{5}{c}{ Sample: 130} \\
\hline Included observations: 30 & & & \\
\hline & & & & \\
\hline Variable & Coefficient & Std. Error & t-Statistic & Prob. \\
\hline C & & & & 0.5623 \\
\hline Wakaf Produktif_X_ & 64782.10 & 110469.5 & 0.586425 & 0.0000 \\
\hline & 1.869258 & 0.230178 & 8.120918 & \\
\hline
\end{tabular}

Dari hasil dari tabel regresi linier sederhana dapat diketahui persamaan regresi sebagai berikut:

$$
Y=64782.10+1.869258 X
$$

Dari persamaan linier sederhana tersebut, dapat dijelaskan bahwa nilai koefisien konstanta sebesar Rp 64782.10 artinya apabila variabel wakaf produktif (modal produksi sawah) konstan maka kesejahteraan masyarakat (pendapatan) juga akan 
konstan sebesar Rp 64782.10. Sementara koefisien variabel wakaf produktif sebesar 1.869258 yang menunjukkan angka positif yang artinya apabila wakaf produktif (modal produksi sawah) meningkat sebesar Rp 1 maka kesejahteraan masyarakat (pendapatan) juga akan meningkat sebesar Rp 1.869258 .

Dari penelitian ini dapat dilihat bahwa nilai koefisien dari konstanta sangat besar yaitu $\mathrm{Rp}$ 64782.10 yang artinya bahwa pemberian tanah wakaf oleh mesjid istiqamah untuk masyarakat sekitar masuh kurang sesuai, seharusnya diberikan kepada masyarakat yang lebih miskin lagi. Karena niat awalnya diberikan tanah wakaf kepada masyarakat adalah untuk membantu mereka agar keluar dari garis kemiskinan.

\section{Hasil Pengujian Hipotesis}

Berdasarkan hasil pengujian, dapat dilihat bahwa wakaf produktif (modal produksi) memiliki nilai t-hitung sebesar 8.120918 dengan nilai probabilitas statistiknya sebesar 0.0000 dan nilai ttabel dengan $(\mathrm{df})=\mathrm{n}-\mathrm{k}(30-2)$ pada $\alpha=0,05$ diperoleh nilai sebesar 2.04841 berarti secara parsial dapat disimpulkan bahwa t-hitung > t-tabel atau $8.120918>2.04841$ maka keputusan hipotesisnya tolak Ho dan terima Ha yang berarti wakaf produktif (X) berpengaruh terhadap meningkatnya kesejahteraan masyarakat (Y) di Mukim Matang Panyang. Hal ini juga bisa dilihat dari probabilitas (P-Value) sebesar $0,0000<0,05$.

Jadi dapat dikatakan bahwa wakaf produktif ini berpengaruh secara signifikan terhadap meningkatnya kesejahteraan masyarakat di mukim Matang Panyang. Dan ini menjadi fokus utama untuk meningkatkan kesejahteraan di mukim Matang panyang yang memiliki jumlah tanah wakaf yang besar.

\section{Hasil Koefisien Korelasi (R) dan Koefisien Diterminasi $\left(\mathbf{R}^{2}\right)$}

\section{a. Hasil Koefisien Korelasi $(\mathbf{R})$}

Analisis koefisien korelasi sederhana digunakan untuk mengetahui keeratan hubungan antara dua variabel dan untuk mengetahui arah hubungan yang terjadi.

Tabel 5. Hasil Regresi

\begin{tabular}{lr}
\hline R-squared & 0.701967 \\
\hline Adjusted R-squared & 0.691323 \\
\hline S.E. of regression & 122449.6 \\
\hline Sum squared resid & $4.20 \mathrm{E}+11$ \\
\hline Log likelihood & -392.9969 \\
\hline F-statistic & 65.94931 \\
\hline Prob(F-statistic) & 0.000000 \\
\hline
\end{tabular}

Untuk melihat hubungan antara satu variabel dengan variabel lain maka digunakanlah uji koefisien korelasi. Seperti yang ada dalam tabel 4.3 terlihat jelas nilai $R$-Squared sebesar 0.701967 jadi $\mathrm{R}===0,837835$ maka hubungan antara wakaf produktif (X) dengan kesejahteraan masyarakat (Y) berhubungan sangat kuat secara positif karena niai $\mathrm{R}$ sebesar 0,837835 .

\section{b. Hasil Koefisien Diterminasi $\left(\mathbf{R}^{2}\right)$}

Nilai $\mathrm{R}^{2}$ disebut juga koefisien diterminasi. Koefisien diterminasi menujukkan seberapa besar presentase variabel bebas dapat menjelaskan variasi variabel terikatnya (goodness of fit test). (Gujarati, 2009).

Untuk melihat koefisien diterminasi maka yang digunakan adalah $R$-Squared. Dan pada tabel 4.3 dapat dilihat nilai $R$-Squared yaitu 0.701967 , jadi wakaf produktif (X) berpengaruh secara positif dan signifikan terhadap kesejahteraan masyarakat
(Y) di Mukim Matang Panyang sebesar 0.701967 (70,19\%). Sedangkan sisanya sebesar 0.298033 atau $29.80 \%$ di pengaruhi oleh faktor lain yang tidak terdapat dalam penelitian ini. Jadi $29.80 \%$ kesejahteraan masyarakat di mukim Matang Panyang dipengaruhi oleh usaha rumah tangga seperti berjualan dan juga montir serta melakukan akad muzaraah (bagi hasil pertanian) dengan warga sekitar.

Semakin banyak wakaf produktif yang diberikan kepada masyarakat maka akan semakin meningkatkan kesejahteraan masyarakat yang mana ini merupakan tujuan dari pemberian wakaf produktif ini. Mukim Matang panyang harus lebih banyak lagi memberikan tanah wakaf kepada masyarakat miskin untuk membantu perekonomian mereka. 


\section{KESIMPULAN}

Berdasarkan hasil penelitian dan pembahasan yang telah dikemukakan dapat ditarik kesimpulan sebagai berikut: Variabel Wakaf Produktif (X) berpengaruh secara signifikan terhadap meningkatnya kesejahteraan masyarakat (Y) di mukim Matang Panyang.

\section{SARAN}

Saran yang dapat digunakan bagi pihak yang ingin melakukan penelitian serupa yaitu:

1. Diharapkan pemberian tanah wakaf ini harus diatur kembali, agar masyarakat miskin dapat menerima harta wakaf tersebut. Jadi hanya diberikan kepada orang-orang yang tidak mampu saja.

2. Diharapkan akan semakin banyak tanah wakaf yang dapat diproduktifkan dengan pemberian kepada masyarakat miskin untuk dikelola

3. Diharapkan lembaga-lembaga wakaf ini lebih antusias memperkenalkan wakaf produktif dikalangan masyarakat..

4. Diharapkan penelitian ini bisa dimanfaatkan untuk pengembangan keilmuan tentang wakaf dan memperdalam pengetahuan tentang wakaf produktif

\section{REFERENSI}

Abdullah, Boedi \& Beni Ahmad Saebani. (2014). Metode Penelitian Ekonomi Islam (Muamalah). Bandung: CV Pustaka Setia.

ADDIN Mendeley Bibliography CSL_BIBLIOGRAPHY Ahmad Suwaidi. (2013). Wakaf Dan Penerapannya Di Negara Muslim. Jurnal Ekonomi Dan Hukum Islam, 3(2), 94-116.

Al-Hadi, A. A. (2009). Upaya Pemberdayaan Tanah Wakaf Produktif Bagi Kesejahteraan Ummat. Islamica, $4(1), 95-107$.

Anas, A., \& Ryandono, M. N. H. (2016). Wakaf Produktif Dalam Pemberantasan Kemiskinan Melalui Pemberdayaan Ekonomi Di Yayasan Nurul Hayat Surabaya. Jurnal Ekonomi Syariah Teori Dan Terapan, 4(3), 253-267.

Damanhur, N. (2016). Analisis Pengaruh Bantuan Zakat Terhadap Tingkat Kesejahteraan Masyarakat Kabupaten Aceh Utara. Jurnal Visioner \& Strategis, 5(2), 71-82.

Damanhur, \& Rahayu, S. (2017). Analisis Aplikasi Akad Ijarah terhadap Pendapatan Petani Tambak Budidaya Ikan Bandeng di Kecamatan Samudera Kabupaten Aceh Utara, 6, 11-21.

Eryanto, H., \& Rika, D. (2013). Pengaruh Modal Budaya, Tingkat Pendidikan Orang Tua Dan Tingkat Pendapatan Orang Tua Terhadap Prestasi Akademik,

Ghozali, Imam. (2012). Aplikasi Analisis Multivariate Dengan Program IBM SPSS 20 Edisi 6. Semarang: UNDIP.

Gujarati, Damodar, N \& Dawn, C. Porter (2009). Dasar-Dasar Ekonometrika (Edisi 5) Terjemahan Eugenia Mardagraha. Jakarta: Selemba Empat.

Hafsah. (2009). Wakaf Produktif Dalam Hukum Islam Indonesia Analisis Filosofis Terhadap UndangUndang RI, XXXIII(1), 84-97.

Hidayat, A. A. (2017). Konsep Harta Perspektif Maqasid Al- Syari` Ah, 11(2), 235-266.

Ibrahim, A. (2014). Stagnansi Perwakafan di Aceh: Analisis Faktor Penyebab. Jurnal Media Syariah, $X V I(1)$,

Ibrahim, A., Khalidin, B., Ahmadsyah, I., \& Ilyas, F. (2015). Prospek Pemanfaatan Tanah Wakaf Di Aceh : Suatu Analisis Untuk Sektor Pendidikan. Human Falah, 2(2), 38-58.

Kasdi, A. (2014). Model Pemberdayaan Wakaf, 1(1), 109-122.

Kasdi, A. (2015). Peran Wakaf Produktif Dalam Pengembangan Pendidikan.

Kasdi, A. (2017). Fiqih wakaf. Yogyakarta: Idea Press Yogyakarta.

Khusaeri, K. (2015). Wakaf Produktif. Al-A'raf: Jurnal Pemikiran Islam Dan Filsafat, 12(1), 77-95.

Medias, F. (2010). Wakaf Produktif Dalam Perspektif Ekonomi Islam. La_Riba, 4(1), 71-86.

Mubarok, Jaih. (2008). Wakaf Produktif. Bandung: Simbiosa Rekatama Media

Mubarok, J. (2008). Wakaf Produktif, 1-16.

Munir, A. S. (2015). Optimalisasi Pemberdayaan Wakaf Secara Produktif. Jurnal Ummul Qura, VI(2), 94109.

Muzlifah, E. (2013). Maqashid Syariah Sebagai Paradigma Dasar Ekonomi Islam. Economic: Jurnal Ekonomi Dan Hukum Islam, 3(2), 177-183.

Nafik, M., Ryandono, H., \& Hazami, B. (2016). Peran dan implementasi waqaf dalam peningkatan kesejahteraan masyarakat. Inferensi, 10(1), 239-264.

Qahaf, Munzir. (2006). Al-Waqf Al-Islami: Tatawwuruhu, Idaratuhu Tanmiyyatuhu, Syiria: Dar al-Fikr Damaskus cet. II

Sancoyowati, F. (n.d.). Mengatasi Eksternalitas Barang Publik ( Perspektif Maqashid Syari’ Ah ), 7-12. 
Supranto, J (2001). Statistik. Teori dan Aplikasi,Edisi ke enam jilid 2. PT. Erlangga, Jakarta

Sugiyono. (2015) Statistika Untuk Penelitian. Bandung: Alfabeta CV.

Sodiq, A. (2016). Konsep Kesejahteraan Dalam Islam. Equilibrium, 3( no. 2), 380-405.

Usman, N. (2014). Wakaf produktif sebagai alternatif sumber dana abadi bagi lembaga pendidikan islam. Tarbiyatuna,

Wiratmadja. (2005). Pengantar Manajemen Dan Pendidikan, 21-33. 